\title{
The degradation of lignin and quantitative aspects of ruminant digestion
}

\author{
By P. PORTER* AND A. G. SINGLETON \\ Department of Physiology, University of Liverpool

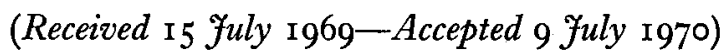

\begin{abstract}
I. The technique for the quantitative estimation of lignin by digestion with $72 \% \mathrm{H}_{2} \mathrm{SO}_{4}$ has been investigated. Two methods of pretreatment designed to eliminate interference products of carbohydrates and proteins were compared, namely $(a)$ acid and pepsin and $(b)$ acid detergent. The latter technique gave low lignin yields owing to the colloidal dispersion of lignin in the acid detergent treatment. Erroneous results arise from an inadequate digestion in $72 \% \mathrm{H}_{2} \mathrm{SO}_{4}$. It was found preferable to filter the product lignin without prior dilution of the acid since white particles of material, assumed to be cellulose, flocculated from solution on dilution. Also there is some loss due to colloidal dispersion of lignin during refluxing in dilute acid.

2. Analysis of soda lignin and sulphuric acid lignin preparations from hay, duodenal contents and faeces of sheep with exteriorized flow through a re-entrant duodenal fistula provided evidence for the degradation of lignin by digestive processes. Demethoxylation of lignin occurred mainly in the stomach, suggesting that this was the main site of breakdown.

3. A new displacement method of measuring duodenal flow is described. Quantitative results obtained also indicate that lignin is degraded mainly in the stomach to the extent of about $10 \%$.

4. These results suggest that faecal lignin is an adequate marker for the estimation of duodenal flow, and hence of the extent of changes in the stomach and intestines respectively.
\end{abstract}

The digestibility of components of the diet in various parts of the ruminant alimentary tract has frequently been studied with lignin as a marker. The possible digestion of lignin is the most serious objection to its use but it has advantages over artificial markers in that it is a natural and integral part of the digesta and food.

The routine laboratory method which has most frequently been used for the estimation of lignin has been the $72 \%$ sulphuric acid technique yielding a crude Klason lignin. The apparent digestibility of lignin has been attributed to the crudeness of the lignin preparation and thus the inaccuracy of the quantitative method. A number of sources of serious experimental error have been found by careful investigation of the technique (Norman \& Jenkins, 1934). Several workers have introduced pretreatments for lignified materials which are designed to eliminate errors introduced by the presence of proteins and carbohydrates which result in condensation products with lignin under the conditions of the $72 \%$ sulphuric acid reaction. Balch, Balch \& Rowland (1954) investigated three techniques (Norman \& Jenkins, I934; Ellis, Matrone \& Maynard, 1946; Armitage, Ashworth \& Ferguson, 1948) and concluded that the crude lignin prepared by the method of Armitage et al. (1948) showed negligible digestibility in dairy cows and considered it an acceptable reference substance for studies of digestion.

In spite of improved techniques, remarkably high digestibility coefficients have been reported for lignin by Bondi \& Meyer (1948), Balch (1957) and Badawy, Campbell, Cuthbertson \& Mackie (1958).

* Present address : Unilever Research Laboratory, Colworth House, Sharnbrook, Bedford. 
The present investigations attempt to assess the site and extent of lignin digestion in sheep with re-entrant duodenal fistulas, and the validity of lignin as a natural marker for studies of digestion. Duodenal flow has been measured by a new displacement method, and lignin in food, duodenal contents and faeces has been isolated and analysed.

\section{EXPERIMENTAL AND RESULTS}

\section{Chemical studies}

\section{Methods of pretreatment for the $72 \% \mathrm{H}_{2} \mathrm{SO}_{4}$ digest}

Faeces and samples of digesta taken from a re-entrant duodenal cannula were freeze-dried and prepared in a finely powdered form by use of a coffee grinder. Finely powdered samples of hay or straw were obtained by chopping, grinding in a hammer mill and finally by treating small samples in a coffee grinder.

Two methods of chemical pretreatment of samples were examined. The purpose of both is to remove protein and hydrolysable polysaccharides and so prevent the formation of condensation products during the $72 \% \mathrm{H}_{2} \mathrm{SO}_{4}$ digest.

Acid and pepsin (Ellis et al. 1946). Samples were first extracted in a Soxhlet apparatus for $4-6 \mathrm{~h}$ with an ethanol: benzene mixture $(\mathrm{r}: 2, \mathrm{v} / \mathrm{v})$ and were hydrolysed with $\mathrm{I}_{5} 5 \mathrm{~N}-\mathrm{H}_{2} \mathrm{SO}_{4}$ at $100^{\circ}$ for $3 \mathrm{~h}$. The residue was filtered, washed with distilled water and then treated with a I \% (w/v) pepsin solution in $0.1 \mathrm{~N}-\mathrm{HCl}$ for $24 \mathrm{~h}$ at $37^{\circ}$.

Acid detergent (Van Soest, 1963 ). Samples were refluxed at $100^{\circ}$ with $2 \%$ cetyl trimethyl ammonium bromide in $\mathrm{r} \cdot 5 \mathrm{~N}-\mathrm{H}_{2} \mathrm{SO}_{4}$ for $2 \mathrm{~h}$.

\section{Isolation of soda lignin and sulphuric acid lignin preparations}

Materials from which lignin preparations were isolated were first subjected to the acid and pepsin pretreatment.

In isolating the soda lignin preparations, the residue after pretreatment of approximately $10 \mathrm{~g}$ of material was extracted with $50 \mathrm{ml}$ of $5 \%(\mathrm{w} / \mathrm{v}) \mathrm{NaOH}$ at room temperature. Extraction was carried out in an atmosphere of nitrogen for $18 \mathrm{~h}$ with continuous shaking. The supernatant fluid was removed after centrifuging and the extraction was repeated for a further $18 \mathrm{~h}$. The extraction was repeated twice more at $5^{\circ}$. The combined soda liquors were diluted with $5 \mathrm{vol}$. distilled water, and neutralized by the addition of $5 \%(\mathrm{v} / \mathrm{v})$ acetic acid. The precipitated lignin was allowed to settle out overnight, the clear supernatant fluid was decanted and the lignin was centrifuged at $2000 \mathrm{~g}$ for $30 \mathrm{~min}$. The lignin was washed three times with demineralized water, suspended in a small volume of water and freeze-dried to yield a brown amorphous powder.

For the isolation of sulphuric acid lignin preparations, the residue after the pretreatment of approximately ro $\mathrm{g}$ of material was covered with cold $72 \% \mathrm{H}_{2} \mathrm{SO}_{4}$ on a sintered crucible (Gallenkamp, porosity $40-9 \circ \mu \mathrm{m}$ ). The dissolved products were allowed to pass slowly through the sinter and the level of acid was carefully maintained in the crucible so that the residue was always covered. This treatment was continued with gentle stirring for $8 \mathrm{~h}$, after which the residue was washed free of acid with distilled water. The lignin was carefully washed from the sinter into a round-bottom 
flask with $0.5 \mathrm{~N}-\mathrm{HCl}$ and the sample was heated at $100^{\circ}$ under reflux for $3 \mathrm{~h}$. The lignin was separated by centrifugation, washed free of acid with distilled water, and freeze-dried from suspension in a small volume of water.

\section{Determination of methoxyl groups}

The semi-micro method of Viebock \& Schwappach (1930) was used as described by Brauns (1952).

\section{Table I. Comparison of effects of different pretreatments on yields and} nitrogen content of fibre and lignin

(Values for faeces are mean values with their standard errors)

\begin{tabular}{|c|c|c|c|c|c|c|}
\hline$\overbrace{\text { Nature }}^{\text {Sample }}$ & No. & Pretreatment & $\begin{array}{l}\text { Residual } \\
\text { fibre } \\
\text { (\% of dry } \\
\text { matter) }\end{array}$ & $\begin{array}{c}\text { Crude } \\
\text { protein } \\
(\mathrm{N} \times 6.25) \\
\text { in fibre } \\
(\% \text { of fibre })\end{array}$ & $\begin{array}{c}72 \% \mathrm{H}_{2} \mathrm{SO}_{4} \\
\text { lignin } \\
\text { (\% of dry } \\
\text { matter) }\end{array}$ & $\begin{array}{c}\mathrm{N} \text { in } \\
\text { lignin } \\
(\% \text { of lignin) }\end{array}$ \\
\hline Faeces & 5 & $\begin{array}{l}\text { Acid and pepsin } \\
\text { Acid detergent }\end{array}$ & $\begin{array}{l}47 \cdot 08 \pm I \cdot I 2 \\
4 I \cdot 33 \pm I \cdot I 5\end{array}$ & $\begin{array}{l}7.19 \pm 0.42 \\
4.92 \pm 0.21\end{array}$ & $\begin{array}{l}21 \cdot 08 \pm 0.62 \\
15 \cdot 72 \pm 0.36\end{array}$ & $\begin{array}{l}1 \cdot 48 \pm 0.16 \\
1.06 \pm 0.02\end{array}$ \\
\hline $\begin{array}{r}\text { Duodenal } \\
\text { contents }\end{array}$ & $\mathbf{I}$ & $\begin{array}{l}\text { Acid and pepsin } \\
\text { Acid detergent }\end{array}$ & $\begin{array}{l}32 \cdot 1 \\
27 \cdot 37\end{array}$ & $\begin{array}{l}5 \cdot 55 \\
3.62\end{array}$ & $\begin{array}{l}9 \cdot 89 \\
6 \cdot 25\end{array}$ & $\begin{array}{l}2 \cdot 33 \\
2 \cdot 13\end{array}$ \\
\hline Hay & $\mathbf{I}$ & $\begin{array}{l}\text { Acid and pepsin } \\
\text { Acid detergent }\end{array}$ & $\begin{array}{l}37 \cdot 22 \\
30 \cdot 05\end{array}$ & $\begin{array}{l}3.84 \\
3.05\end{array}$ & $\begin{array}{l}6 \cdot 68 \\
4 \cdot 48\end{array}$ & $\begin{array}{l}2 \cdot 08 \\
1 \cdot 53\end{array}$ \\
\hline
\end{tabular}

Table 2. Percentage loss of weight of soda lignins when treated with different solutions at $100^{\circ}$ for $3 h$

\begin{tabular}{|c|c|c|c|}
\hline \multirow[b]{2}{*}{ Source of lignin } & \multicolumn{3}{|c|}{ Treatment with } \\
\hline & Water & $\mathrm{I} \cdot 5 \mathrm{~N}-\mathrm{H}_{2} \mathrm{SO}_{4}$ & $\begin{array}{c}\text { Acid } \\
\text { detergent }\end{array}$ \\
\hline Straw & 10.19 & $11 \cdot 22$ & $21 \cdot 40$ \\
\hline $\begin{array}{l}\text { Faeces from straw-fed } \\
\text { sheep }\end{array}$ & $5 \cdot 81$ & $6 \cdot 76$ & $28 \cdot 49$ \\
\hline Hay & $10.4 \mathrm{I}$ & 15.65 & $39 \cdot 62$ \\
\hline $\begin{array}{l}\text { Duodenal contents } \\
\text { from hay-fed sheep }\end{array}$ & $10 \cdot 76$ & 16.09 & $38 \cdot 65$ \\
\hline $\begin{array}{l}\text { Faeces from hay-fed } \\
\text { sheep }\end{array}$ & II $\cdot 87$ & 10.48 & $42 \cdot 29$ \\
\hline
\end{tabular}

\section{Determination of nitrogen}

The micro-Kjeldahl method was used with a catalyst consisting of $\mathrm{CuSO}_{4}: \mathrm{K}_{2} \mathrm{SO}_{4}$ $(\mathrm{I}: 4, \mathrm{w} / \mathrm{w})$. Protein was calculated as $\mathrm{N} \times 6 \cdot 25$.

\section{Effect of pretreatment on lignin preparation}

Lignin consists of polymerized phenolic compounds (Freudenberg, 1965) and is essentially free of nitrogen-containing components. The crude lignin isolated from most natural sources by treatment with $72 \% \mathrm{H}_{2} \mathrm{SO}_{4}$ contains nitrogen. Most methods for estimation of lignin attempt to remove nitrogenous components before treatment of the sample with $72 \% \mathrm{H}_{2} \mathrm{SO}_{4}$.

Two methods of pretreatment were compared: the acid detergent method of Van 
Soest (1963) and the acid and pepsin method of Ellis et al. (1946). The former yielded fibre residues containing less nitrogen (Table I), possibly producing less interference products by the contact effect in the $72 \% \mathrm{H}_{2} \mathrm{SO}_{4}$ digest.

The yields of lignin by the acid detergent method were considerably lower than those by the acid and pepsin method. The reason for the lower lignin yield was indicated when prepared soda lignins were subject to the pretreatment conditions (Table 2). The lignins tended to form colloidal solutions in water or acid and could be recovered by salting out procedures or $\mathrm{pH}$ change. The acid detergent had a strong peptising effect and the colloidal lignin could not be recovered by salting out techniques or change of $\mathrm{pH}$.

It was difficult to obtain reproducible results with the acid detergent technique. This was probably due to variability in the colloidal dispersion of lignin during the pretreatment conditions. We therefore favoured the acid and pepsin method of pretreatment and this of course had the advantage of producing a smaller loss in yield of total product. The yield of lignin from hay, straw and faeces by the acid detergent method usually approximated to $60 \%$ of that given by the acid and pepsin method.

\section{Effect of the duration of $72 \% \mathrm{H}_{2} \mathrm{SO}_{4}$ treatment upon the lignin yield}

Norman \& Jenkins (1934) observed that proteins and certain sugars increase the yields of lignin determined by the $72 \% \mathrm{H}_{2} \mathrm{SO}_{4}$ method. This interference was due to condensation between lignin and these compounds. The error produced increased with the time of contact. The minimal effect was considered to take place at $2 \mathrm{~h}$ and, as a result, most descriptions of the $72 \% \mathrm{H}_{2} \mathrm{SO}_{4}$ technique stipulate a digestion time of $2 \mathrm{~h}$ in order to minimize such errors. This problem was reinvestigated and an experiment was conducted in two parts. In the first experiment the samples were digested in beakers so that the products of reaction were in contact with the lignin residue throughout the period of the reaction. In the second experiment the samples were digested in sintered crucibles so that the acid required to be continually replaced and the products of reaction were removed from contact with the lignin.

The experiments were conducted concurrently with hay and faeces which had been extracted with ethanol: benzene $(\mathrm{I}: 2, \mathrm{v} / \mathrm{v})$ in a Soxhlet apparatus for $3 \mathrm{~h}$ and then refluxed with $\mathrm{I}_{5} 5 \mathrm{~N}-\mathrm{H}_{2} \mathrm{SO}_{4}$ at $100^{\circ}$ for $6 \mathrm{~h}$ and dried. Each sample ( $150 \mathrm{mg}$ ) was made into a paste with ice-cold $72 \% \mathrm{H}_{2} \mathrm{SO}_{4}$ and then stirred with $20 \mathrm{ml}$ of acid. The mixtures were stirred continually throughout the period of the reaction and further amounts of acid were added to the sintered crucibles as required to maintain the level. The treatment of the residual material differed for each experiment. The residue in the sinter method was washed free of acid with hot water; in the beaker method the reaction mixture was diluted to $5 \%$ acid concentration and refluxed for $3 \mathrm{~h}$ before filtering on to weighed sintered crucibles (Ellis et al. 1946). The lignin values were corrected for ash content of the fraction which was determined by ashing at $500^{\circ}$ for I6 h.

Fig. $\mathrm{I}$ shows that $2 \mathrm{~h}$ reaction time with $72 \% \mathrm{H}_{2} \mathrm{SO}_{4}$ is not sufficient to bring about a complete digestion. This was made particularly apparent in the beaker digestion when the dilution of the reaction mixture brought about the flocculation of white 
particles. The subsequent refluxing at $100^{\circ}$ for $3 \mathrm{~h}$ in $5 \% \mathrm{H}_{2} \mathrm{SO}_{4}$ was without effect on the precipitate and it remained with the lignin, giving rise to artificially high values. The precipitated material was assumed to be cellulose since other polysaccharides are hydrolysed under these conditions. This effect was not apparent in the sinteredcrucible digestion, but the results proved that not all the digestible material was removed within 4 h. The 'contact effect' of Norman \& Jenkins (1934) was apparent

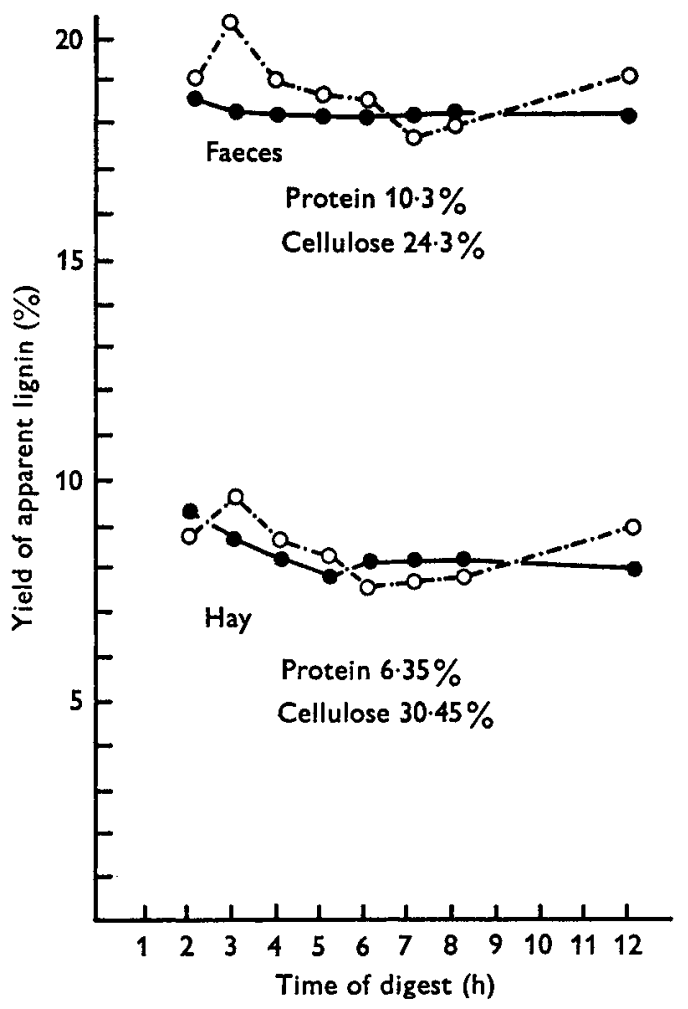

Fig. I. Effect of length of time of $72 \% \mathrm{H}_{2} \mathrm{SO}_{4}$ digest on the yield of apparent lignin from hay and faeces. $O$, digest in beakers followed by dilution and reflux; $\boldsymbol{O}$, digest in sintered crucibles followed by washing with hot water.

in the beaker method when the digestion time extended to $12 \mathrm{~h}$. The error introduced here is small owing to the pretreatment of the material, but it is more serious for the faeces where there is a higher proportion of crude protein than in hay.

A further source of error emerges from the lignin values obtained after 6 and $7 \mathrm{~h}$ treatment with $72 \% \mathrm{H}_{2} \mathrm{SO}_{4}$. At this time the 'cellulose effect' and the 'contact effect' are not apparent in the beaker method, but the results proved to be lower than those obtained in the sinter method. It appeared probable that subsequent refluxing for $3 \mathrm{~h}$ in a $5 \%$ concentration of acid might lead to a loss of lignin which did not arise when the residue from digestion with $72 \% \mathrm{H}_{2} \mathrm{SO}_{4}$ was merely washed with water. This was confirmed by studies with modified lignins which are described below. 


\section{Animals}

\section{Animal experiments}

Re-entrant duodenal fistulas were prepared in three adult Clun Forest cross-bred sheep as described by Singleton (196I). Experiments were carried out at a time after surgery when food intake and faeces output had reached pre-operative levels.

\section{Digestibility trials}

During digestibility trials the sheep were maintained in metabolism cages and fed twice daily (08.30 and 16.30 hours); food residues were recorded. The trials lasted I week. Faeces were weighed daily and representative samples were taken for freezedrying.

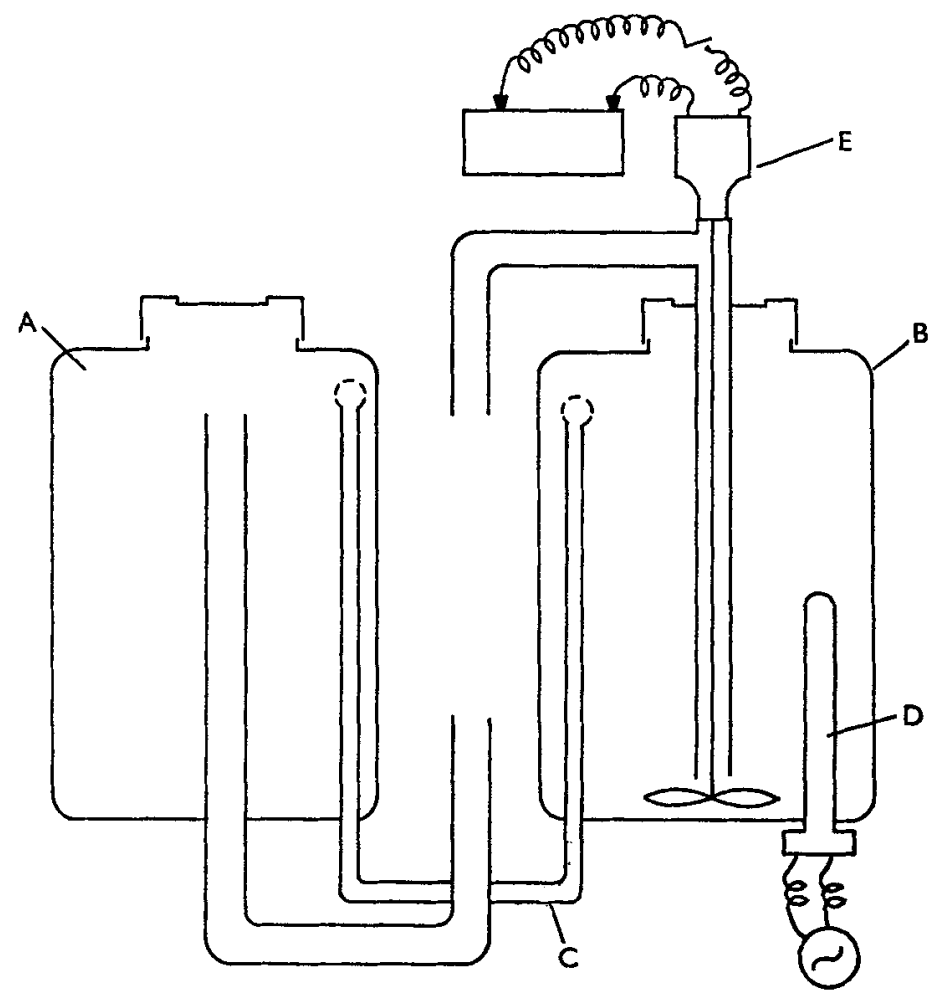

Fig. 2. Displacement apparatus for measurement and sampling of duodenal flow. A, I 1 plastic receiving vessel with airtight screw-cap; $B$, storage vessel for duodenal return; $C$, airpipe to equilibrate pressure between vessels; $D$, thermostatically controlled heater; $E$, batteryoperated stirrer.

\section{Displacement method for measurement of duodenal flow}

The apparatus used is shown diagrammatically in Fig. 2. Two wide-mouthed polyethylene bottles with screw caps (A and $B$ ) were suspended on the right side of the sheep by means of a canvas saddle, and were counterbalanced by small lead weights on the left side. Bottle B was filled with duodenal contents collected before the experiment began, and was provided with a battery-driven stirrer and a thermostatically 
controlled heater. Bottle $A$ was connected to the cannula nearest to the abomasum by the wide tube passing through the base and, as digesta flowed into the bottle from the fistula, air was displaced into bottle B. This forced an equivalent quantity of duodenal contents up the central tube and into the other duodenal cannula. Bottle A gradually filled, and at appropriate intervals (about $0.5 \mathrm{~h}$ ) the contents were removed by a suction pump, their volume was measured, and a $100 \mathrm{ml}$ sample was taken for freeze-drying and analysis. The remainder was used to replenish bottle $B$, the volume of the sample being replaced from previously collected duodenal contents. The latter also served to prime bottle $B$ during the ist hour of collection. The equipment is light in weight, the sheep is able to stand or lie down, and measurements can be made for long periods without the animal becoming fatigued. It allows the normal backwards and forwards flow from each cannula, and ensures that material similar in quantity and quality is returned to the duodenum as it leaves the abomasum. These factors are probably of importance in regulating the rate of flow (Singleton, 195 I).

The flow of duodenal contents was measured and sampled during four separate $6 \mathrm{~h}$ periods within $48 \mathrm{~h}$ so that every hour of the $24 \mathrm{~h}$ day was accounted for during this time.

Table 3. Composition of soda lignin preparation from food and faeces of sheep given hay or straw

\begin{tabular}{|c|c|c|c|c|c|}
\hline \multirow{3}{*}{$\begin{array}{l}\text { Source of } \\
\text { lignin }\end{array}$} & \multirow{3}{*}{$\begin{array}{c}\text { Yield (\% of } \\
\mathrm{H}_{2} \mathrm{SO}_{4} \text { lignin) }\end{array}$} & \multicolumn{4}{|c|}{ Soda lignin } \\
\hline & & $\begin{array}{c}\text { C } \\
\text { content }\end{array}$ & $\begin{array}{c}\mathrm{H} \\
\text { content }\end{array}$ & $\underset{\text { content }}{\mathrm{N}}$ & $\begin{array}{l}\text { Methoxyl } \\
\text { content }\end{array}$ \\
\hline & & \multicolumn{4}{|c|}{ (\% of ash-free lignin) } \\
\hline Hay & $60 \cdot 31$ & $57 \cdot 60$ & $5 \cdot 96$ & $x \cdot 75$ & 10.51 \\
\hline $\begin{array}{l}\text { Faeces of sheep } \\
\text { given hay }\end{array}$ & $65 \cdot 45$ & $56 \cdot 85$ & $5 \cdot 59$ & $1 \cdot 76$ & $8 \cdot 44$ \\
\hline Straw & $75 \cdot 8$ & $57 \cdot 59$ & $5 \cdot 67$ & $1 \cdot 08$ & 13.42 \\
\hline $\begin{array}{l}\text { Faeces of sheep } \\
\text { given oat straw }\end{array}$ & $72 \cdot 2$ & $5^{8 \cdot 06}$ & $5 \cdot 95$ & $1 \cdot 69$ & $8 \cdot 92$ \\
\hline
\end{tabular}

\section{Analytical evidence for the degradation of lignin by the digestive processes of the sheep}

Preliminary studies were conducted with two sheep to determine if lignin was unaffected in its passage through the ruminant alimentary tract. The sheep were maintained in metabolism cages; one was given hay and the other oat straw. Lignin was prepared by sodium hydroxide extraction since this method of isolation is considered to yield a product which is more representative of native lignin (Brauns, 1952). The isolated lignin was subjected to empirical analysis for carbon, hydrogen and nitrogen, and examined for content of methoxyl groups by the method of Viebock \& Schwappach (1930) as Csonka, Phillips \& Jones (1929) had shown that lignin was demethoxylated in the stomach of both the cow and the dog.

The yield of lignin obtained by extraction of samples with sodium hydroxide under nitrogen was more than $60 \%$ of that obtained by the $72 \% \mathrm{H}_{2} \mathrm{SO}_{4}$ technique (Table 3 ) using the pretreatment of Ellis et al. (1946). The analyses for carbon, hydrogen and nitrogen in the lignin preparations showed little change between food and faeces in 
each study. However, the methoxyl content of the faecal lignin was considerably less than the food in each instance, a $19.2 \%$ reduction resulting in the lignin of the hay diet and $33.5 \%$ reduction in the lignin of the straw diet.

Investigations were conducted to establish the extent to which the change in composition took place in the stomachs and in the intestines respectively. Soda lignins from the hay, duodenal contents and faeces of a sheep with a re-entrant duodenal fistula were prepared and analysed (Table 4). The analyses for carbon, hydrogen and nitrogen did not show any considerable variation but the demethoxylation process was shown to take place mainly in the stomach.

Table 4. Composition of soda lignin preparations of food, duodenal contents and faeces of a sheep given hay

\begin{tabular}{|c|c|c|c|c|}
\hline \multirow[b]{2}{*}{ Source of lignin } & \multicolumn{4}{|c|}{ Soda lignin } \\
\hline & $\underset{\text { content }}{\mathbf{C}}$ & $\underset{\text { content }}{\mathrm{H}}$ & $\underset{\text { content }}{\mathrm{N}}$ & $\begin{array}{c}\text { Methoxyl } \\
\text { content }\end{array}$ \\
\hline & \multicolumn{4}{|c|}{ ( $\%$ of ash-free lignin) } \\
\hline $\begin{array}{l}\text { Hay } \\
\text { Duodenal contents } \\
\text { Faeces }\end{array}$ & $\begin{array}{l}58 \cdot 33 \\
58 \cdot 21 \\
58 \cdot 38\end{array}$ & $\begin{array}{l}6 \cdot 44 \\
6 \cdot 56 \\
6 \cdot 09\end{array}$ & $\begin{array}{l}I \cdot 70 \\
2 \cdot 00 \\
I \cdot 41\end{array}$ & $\begin{array}{r}10 \cdot 41 \\
8 \cdot 95 \\
8 \cdot 69\end{array}$ \\
\hline
\end{tabular}

Table 5. Composition of sulphuric acid lignins from hay, duodenal contents and faeces of a sheep given hay

\begin{tabular}{|c|c|c|c|c|c|c|}
\hline \multirow[b]{3}{*}{ Pretreatment } & \multirow{3}{*}{$\begin{array}{l}\text { Source } \\
\text { of lignin }\end{array}$} & \multicolumn{4}{|c|}{$\mathrm{H}_{2} \mathrm{SO}_{4}$ lignin } & \multirow[b]{2}{*}{$\begin{array}{c}\text { Methoxyl } \\
\text { content }\end{array}$} \\
\hline & & \multirow{2}{*}{$\begin{array}{l}\text { Amount } \\
\text { (\% of } \\
\text { dry } \\
\text { matter) }\end{array}$} & $\begin{array}{c}\text { C } \\
\text { content }\end{array}$ & $\begin{array}{c}\mathrm{H} \\
\text { content }\end{array}$ & $\underset{\text { content }}{\mathrm{N}}$ & \\
\hline & & & \multicolumn{4}{|c|}{ ( $\%$ of ash-free lignin) } \\
\hline \multirow{3}{*}{$\begin{array}{l}\text { Acid and } \\
\text { pepsin }\end{array}$} & & $7 \cdot 17$ & $58 \cdot 36$ & $6 \cdot 16$ & $2 \cdot 20$ & 10.19 \\
\hline & $\begin{array}{c}\text { Duodenal } \\
\text { contents }\end{array}$ & 13.69 & $55 \cdot 73$ & $5 \cdot 34$ & $2 \cdot 48$ & $9 \cdot 21$ \\
\hline & Faeces & $20 \cdot 86$ & $56 \cdot 63$ & $4 \cdot 81$ & $2 \cdot 10$ & 9.02 \\
\hline \multirow[t]{2}{*}{$\begin{array}{l}\text { Acid } \\
\text { detergent }\end{array}$} & $\begin{array}{l}\text { Hay } \\
\text { Duodenal } \\
\text { contents }\end{array}$ & $\begin{array}{l}4.63 \\
8.63\end{array}$ & $\begin{array}{l}60 \cdot 03 \\
60 \cdot 00\end{array}$ & $\begin{array}{l}6 \cdot 84 \\
6 \cdot 23\end{array}$ & $\begin{array}{l}1 \cdot 75 \\
2 \cdot 37\end{array}$ & $\begin{array}{r}10.31 \\
8 \cdot 71\end{array}$ \\
\hline & Faeces & $12 \cdot 82$ & $59 \cdot 66$ & $6 \cdot 46$ & $1 \cdot 75$ & $8 \cdot 73$ \\
\hline
\end{tabular}

The lignin prepared by sodium hydroxide extraction is isolated under milder chemical conditions than that yielded by the $72 \% \mathrm{H}_{2} \mathrm{SO}_{4}$ technique. However, the $72 \% \mathrm{H}_{2} \mathrm{SO}_{4}$ method has the advantage of being relatively uncomplicated and simpler to adapt as a quantitative method. From this standpoint, in studying the validity of lignin as a quantitative marker, it becomes necessary to establish that the changes which have been shown to take place in soda lignin preparations are similarly demonstrable in sulphuric acid lignins.

By the two methods of pretreatment previously described, sulphuric acid lignins were prepared from hay, duodenal contents, and faeces from sheep given hay. The composition of the lignin preparations from each method of pretreatment is given in Table 5. The elementary composition of the sulphuric acid lignins yielded by the 
acid detergent method of pretreatment changed very little between food, duodenal contents and faeces. There was, however, a $16 \%$ fall in methoxyl content of the lignin between food and faeces and this took place entirely in the stomach.

The composition of the lignins prepared by the acid and pepsin method of pretreatment was more variable. This could possibly be due to some contamination resulting from condensation products formed in the treatment with $72 \% \mathrm{H}_{2} \mathrm{SO}_{4}$, since the nitrogen content was higher than in preparations yielded by the acid detergent technique or by extraction with sodium hydroxide. The main change in composition occurred in the stomach and this again was the main site for demethoxylation.

\section{The passage of lignin from the stomach of the sheep}

Possessing this chemical evidence for the degradation of lignin, we endeavoured to produce direct evidence for its disappearance from the alimentary tract. This was obtained from digestibility trials with sheep maintained in metabolism cages. The

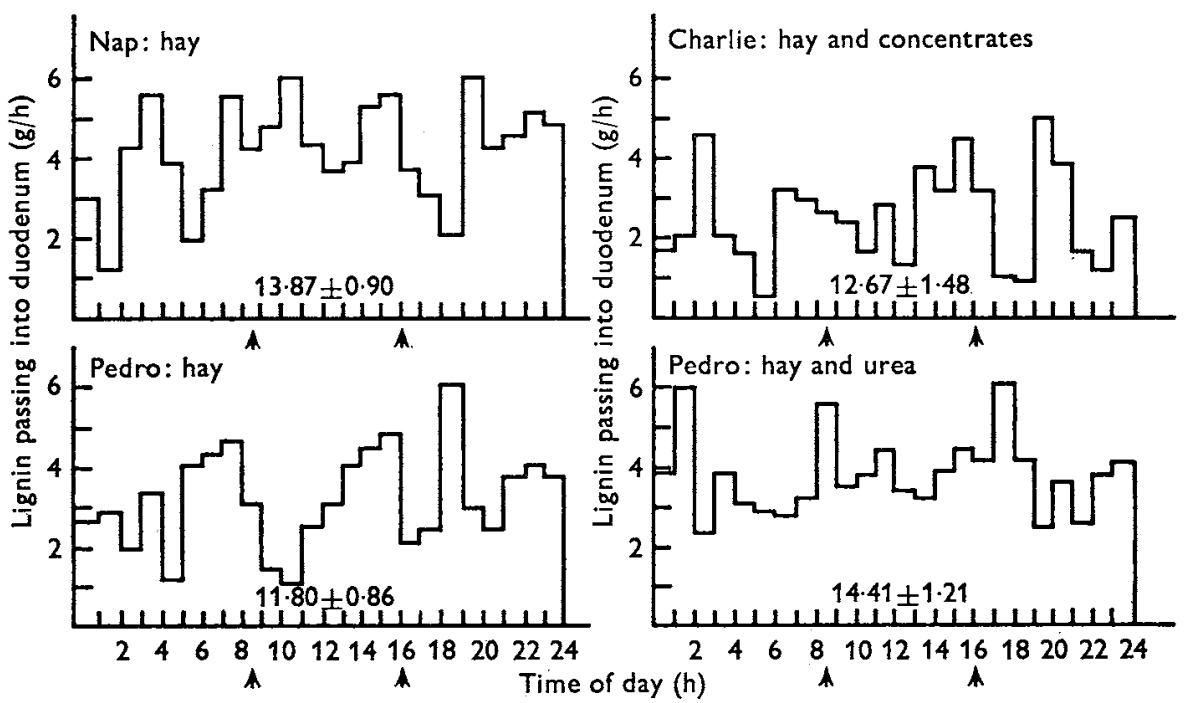

Fig. 3. Hourly variation in the quantity of lignin passing into the duodenum of sheep. The mean lignin concentrations in dry matter, with their standard errors, in the duodenal content measured each hour are shown by the figures inside the histograms. Feeding times are indicated by arrows.

sheep were given hay, hay and concentrates, hay and urea, and straw. Lignins were determined by the acid and pepsin method, and in nine trials digestibilities for lignin, calculated as

$$
\left(\mathrm{r}-\frac{\text { faecal lignin }}{\text { diet lignin }}\right) \times 100 \% \text {, }
$$

were recorded in the range $\mathrm{I} \cdot 2-\mathrm{I} 0 \cdot 2 \%$. This did no more than confirm the findings of many other workers. It was necessary, however, to establish that the apparent digestion of lignin was not due to errors in its method of determination. 
The chemical evidence suggests that degradation of lignin takes place mainly in the stomach. Experiments were conducted in three sheep with re-entrant duodenal fistulas to obtain a quantitative estimate of lignin degradation. The quantities of lignin passing per hour from the stomach were calculated from the volume of digesta flowing through the duodenum and the lignin concentration. The rate of passage of lignin into the duodenum in four experiments using three sheep is shown in Fig. 3. The quantities of lignin entering the duodenum per hour vary considerably, mainly because of the large difference in flow, but partly as a result of variation in dry-matter concentration of the duodenal contents. Lignin formed a fairly consistent proportion of the dry

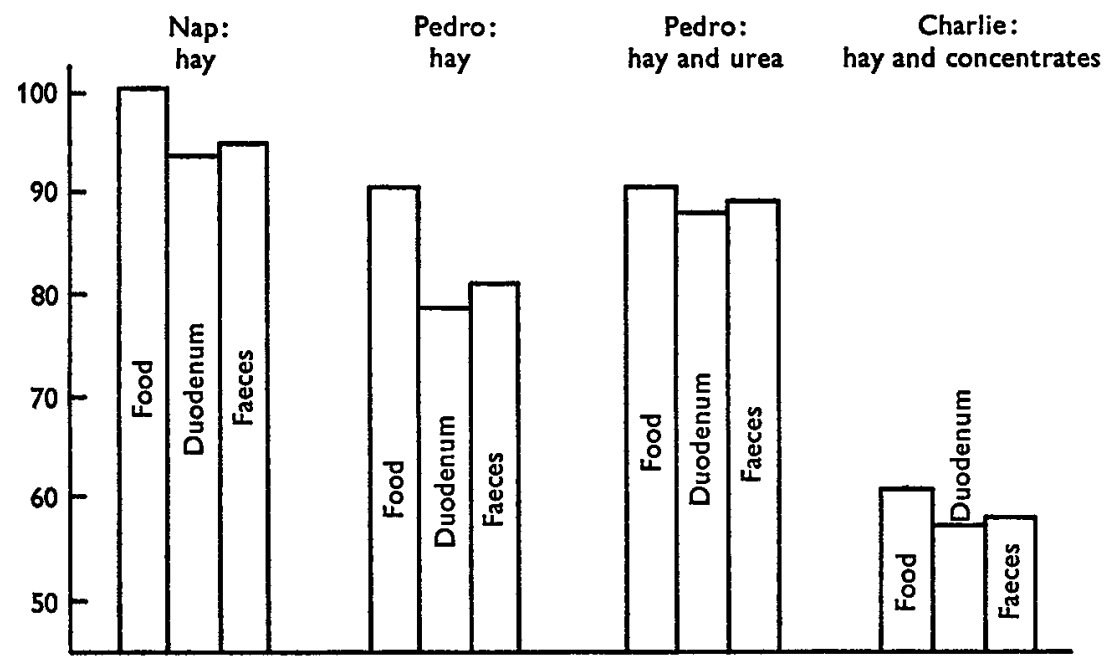

Fig. 4. The dietary intake of lignin by sheep compared with the amounts appearing in the duodenum and faeces per $24 \mathrm{~h}$.

matter of the digesta. The variability in the lignin values expressed as a percentage of the dry matter for each hourly sample of duodenal contents throughout the $24 \mathrm{~h}$ period is indicated by the values within the histogram for each experiment (Fig. 3).

The recovery of lignin in $24 \mathrm{~h}$ from the duodenum, though similar to the daily excretion in the faeces, was always slightly less, possibly owing to underestimation of duodenal flow. Nevertheless, the results suggest that little degradation of lignin occurs in the intestines (Fig. 4).

\section{DISCUSSION}

The errors attending the estimation of crude lignin have probably been the main drawback in the use of lignin as a marker for ruminant digestion studies. Close examination of the technique by Norman \& Jenkins (1934), Ellis et al. (1946), Moon \& Abou-Raya (1952) and Czerkawski (1967) has largely accounted for and eliminated the major sources of error. Studies with soda lignin (Table 2) have indicated that the pretreatment conditions used to remove components which lead to condensation products during the reaction with $72 \% \mathrm{H}_{2} \mathrm{SO}_{4}$ may in fact result in a loss of lignin due to colloidal dispersion. Incomplete digestion of the material in $72 \% \mathrm{H}_{2} \mathrm{SO}_{4}$ is also a 
source of error and it is preferable that the product lignin should be filtered without prior dilution of the acid.

The digestibility studies indicated that as much as $10.2 \%$ of the lignin of the diet may disappear in the alimentary tract of the sheep. Chemical analyses indicated that demethoxylation of the lignin takes place and that the site of this action is mainly in the stomach. This evidence confirms the findings of Csonka et al. (1929) in studies with a cow. The studies of the flow of lignin to the duodenum of the sheep provide supporting evidence that the main site for the digestion of lignin is the stomach. In previous experiments on sheep on similar diets we found very little digestion of fibre polysaccharides in the intestines (Porter \& Singleton, $1965 a, b, \mathrm{I} 966$ ). On the basis of this evidence, it would appear unlikely that the intestines would play a part in the digestion of lignin, which is the least digestible component of the fibre structure.

It is natural to suspect that the rumen microflora may be responsible for digestion of lignin, since the biological degradation of lignin, which takes place on such a tremendous scale in nature, is a result of the action of micro-organisms. However, Phillips, Weihe, Jones \& Csonka (1929) showed that demethoxylation of lignin takes place in the digestive tract of the dog as well as the cow and, from in vitro studies, Csonka et al. (1929) claimed that the demethoxylation of lignin could be brought about by some agent other than bacteria, possibly an enzyme present in the gastric juice of the animal.

The chemical composition and the quantity of lignin passing through the duodenum closely match those of the faecal lignin. Thus for studies of events in the intestines the digestibility of lignin need not be a serious objection if the faeces rather than the food lignin is used as a quantitative marker. The quantitative collection of faeces is in many ways preferable to a quantitative assessment of food intake. It is also a very simple matter compared with the quantitative sampling of material from a re-entrant fistula in the intestines. From a knowledge of the total $24 \mathrm{~h}$ passage of lignin in the faeces and the analyses of representative samples of digesta, it would be possible to assess the digestion of various constituents of the diet using the lignin ratio technique. The relative constancy of lignin estimated as a proportion of dry matter in the duodenal contents in each experiment suggests that the total amount of dry matter passing through the duodenum in $24 \mathrm{~h}$ may be reasonably accurately assessed from the mean value of a few samples taken at intervals during the day and night.

The quantity of lignin passing through the duodenum, as assessed by flow measurement, was similar to the quantity in faeces, supporting the view that little or no lignin is degraded in the intestine. However, Harris \& Phillipson (1964), using chromium sesquioxide as a marker, found that duodenal flow as measured was less than that estimated from marker concentration, and concluded that flow was depressed by the process of measurement. Since a different method of flow measurement was used in the present experiments, the results are not directly comparable, and our results indicate that, at least in these experiments, the quantity of faecal lignin provides a basis for the calculation of duodenal flow. 
This work was carried out with the valued technical assistance of Miss R. Cook and $\mathrm{Mr}$ J. Stowell, and we gratefully acknowledge financial support from the Agricultural Research Council.

\section{REFERENCES}

Armitage, E. R., Ashworth, R. B. \& Ferguson, W. S. (1948). F. Soc. chem. Ind. 67, 24I.

Badawy, A. M., Campbell, R. M., Cuthbertson, D. P. \& Mackie, W. S. (1958). Br. F. Nutr. $12,367$.

Balch, C. C. (1957). Br. F. Nutr. Ir, 213.

Balch, D. A., Balch, C. C. \& Rowland, S. J. (1954). F. Sci, Fd Agric. 5, 584.

Bondi, A. \& Meyer, H. (1948). Biochem. F. 43, 248.

Brauns, F. E. (1952). Chemistry of Lignin. New York: Academic Press, Inc.

Csonka, F. A., Phillips, M. \& Jones, D. B. (1929). F. biol. Chem. 85, 65.

Czerkawski, J. W. (1967). Br. Y. Nutr. 21, 325.

Ellis, G. H., Matrone, G \& Maynard, L. A. (1946). F. Anim. Sci. 5, 285.

Freudenberg, K. (1965). Science, N.Y. r48, 595 .

Harris, L. E. \& Phillipson, A. T. (1964). Anim. Prod. 4, 97.

Moon, F. E. \& Abou-Raya, A. K. (1952). F. Sci. Fd Agric. 3, 399.

Norman, A. G. \& Jenkins, A. H. (1934). Biochem. F. 28, 2 I60.

Phillips, M., Weihe, H., Jones, D. B. \& Csonka, F. A. (1929). Proc. Soc. exp. Biol. Med. $26,320$.

Porter, P. \& Singleton, A. G. (1965a). Biochem. 7. 96, $59 P$.

Porter, P. \& Singleton, A. G. (1965b). Y. Physiol., Lond. 183, 73 P.

Porter, P. \& Singleton, A. G. (1966). F. Physiol., Lond. 186, 145 P.

Singleton, A. G. (1951). F. Physiol., Lond. Ir5, 73 P.

Singleton, A. G. (1961). F. Physiol., Lond. 155, 134.

Van Soest, P. J. (1963). F. Ass. off. agric. Chem. 46, 829.

Viebock, F. \& Schwappach, H. (1930). Ber. 63, 2818. Quoted by Brauns, F. E. (1952). 